The Quarterly Journal of Austrian Economics

Volume 22 | No. 2 | 242-270 | SuMmer 2019 WWW.QJAE.ORG

\title{
Ludwig von Mises, Sociology, and Metatheory
}

\author{
Christian Robitaille*
}

JEL Classification: B53, Y80

Aвstract: This paper discusses the epistemological status and potential scope of the discipline of sociology based on the writings of Ludwig von Mises. More specifically, it presents his epistemological distinction between theory and history, and argues that sociology can be integrated in this framework as a historical discipline. As such, it must be a praxeologically guided study of general or specific social phenomena that already occurred or are likely to occur. Additionally, this paper addresses the general insights provided by Mises to questions of interest to the field of sociologythe division of labor and the evolution of society, the social effects of socialism and capitalism, class analysis, and the role of ideas in social change-in order to infer from it the general tasks that sociology, as a historical discipline, can accomplish in its study of social phenomena.

T udwig von Mises's contributions to economics are widely Lnnown. For instance, his application of Carl Menger's subjective theory of value to money (Mises [1912] 1953), his description of the necessary economic failure of any socialist regime (Mises [1920] 1963; [1922] 1951), and his reconstruction of economics as a theory of human action (Mises [1949] 1998) all stand as important contributions to the development of Austrian economics. But Mises was more than an economist; he was also a philosopher and sociologist.

*Christian Robitaille (crobi112@uottawa.ca) is a doctoral student at the University of Ottawa. 
However, many of his insights to these fields of study are less well known. There is the work of Salerno (1990), which identifies reason, ideology, and the division of labor as the main vectors for social change in the Misesian interpretation of history. There is also the more recent comparison between the social rationalism of Mises and that of the French Idéologue Destutt de Tracy by Dorobăț (2015), as well as a comparison between the social theories of Mises and of French sociologist Raymond Boudon by Fillieule (2014). Finally, we can find studies in which Mises's work is compared to Max Weber's work (Schütz 1967; Boettke and Storr 2002; Anderson 2004; Callahan 2007; Zafirovski 2010). However, there still lacks a more general analysis linking Mises's epistemology with his answers to the particular questions sociologists have attempted to address. This general analysis will allow us to see the extent to which the study of Mises's work can help sociologists understand the social world.

This article is therefore guided by two different but interconnected goals. In the first section of this paper, I want to explain how sociology can be understood in light of Mises's general epistemological distinction between theory and history. Second, I want to present an outline of the general answers he provided to some of the most important questions that sociologists sought to address. From this, it will become possible to understand how a Misesian sociological investigation can be conducted.

\section{ON SOCIAL THEORY AND HISTORY}

Ludwig von Mises's distinction between theory and history is perhaps one of his most general and useful epistemological insights. In short, theory constitutes the set of all praxeological categories (and a priori laws) framing our knowledge whereas history constitutes the description and analysis of particular or general empirical events or trends (Mises 1962, 44-6).

Theory and history are complementary. Indeed, Mises writes: "The fullness of reality can be mentally mastered only by a mind resorting both to the conception of praxeology and to the understanding of history" (Mises [1949] 1998, 642-43). Without theory, social scientists cannot meaningfully grasp and understand the 
empirical data of history ${ }^{1}$; without history, they are condemned to know what limits their knowledge of the social world without ever using (applying) those limits to understand specific empirical events. In other words, theory (praxeology) provides boundaries to the set of possible interpretations about historical (empirical) reality. One cannot make sense of history if one does not know how to frame one's interpretations. ${ }^{2}$ Praxeology therefore provides the conditions of possibility of the understanding of history: "Experience concerning human action," Mises writes, "presupposes the category of human action and all that derives from it. If one does not refer to the system of the praxeological a priori, one must not and cannot talk of action" (Mises 1962, 42). Also, "Understanding presupposes and implies the logical structure of the human mind with all the a priori categories." (Mises 1962, 48).

As Hoppe $(1995,20,81)$ indicates, following Mises, it is because action is both a mental and an external process that one can acquire theoretical (a priori) knowledge about what frames historical (empirical) understanding. ${ }^{3}$ Mises $(1962,42)$ indeed writes: "Both, a priori thinking and reasoning on the one hand and human action on the other, are the manifestations of the human mind. [...] Reason and action are congeneric and homogeneous, two aspects of the same phenomenon." Indeed, action is external behavior guided by thinking and reasoning; and the structure of action is discoverable through thinking about action. It thus frames its real-externalmanifestations and, thereby, also frames thoughts about these external manifestations. Historical data provide a record of these empirical events whereas praxeological concepts provide the

\footnotetext{
${ }^{1}$ On the necessity of conceiving empirical knowledge as being praxeologically framed, see Hoppe $(1995,69-70)$.

${ }^{2}$ On the necessity of a "common ground" to determine the validity or possibility of a claim or interpretation and, in particular, on praxeology as such a common ground, see Hoppe (1989). As Mises $(1962,2)$ puts it: "For epistemology there is something that it must take as unchanging, viz., the logical and praxeological structure of the human mind." Indeed, "knowledge is a tool of action. Its function is to advise man how to proceed in his endeavors to remove uneasiness." And "the pure search for knowledge, not motivated by the desire to improve the external conditions of life, is also an action, i.e., an effort to attain a more desirable state of affairs." (Mises 1962, 35).

${ }^{3}$ The same applies for predictions about future empirical events. See Hoppe (1995, $43-46,81 ; 1997)$.
} 
boundaries within which one can think about what caused these external manifestations. And the usefulness of these concepts depends on the extent to which they allow us to understand real actions. For instance, the praxeological law according to which every voluntary exchange is mutually beneficial is only useful to our knowledge if in history there was indeed (or we expect that there will be in the future) actors proceeding to what we know to be a voluntary exchange. There would be no need for a theory of exchange if we lived in a world where no exchange ever occurs. Theory must thus address, frame, and impose limits on the understanding of phenomena that occurred (or are likely to occur) in order to be useful (Mises 1962, 41).

With this in mind, it is possible to address the question of the epistemological status of sociology according to Mises.

\subsection{Theory, History, and the Epistemological Status of Sociology}

Other than the quite trivial claim that sociology is the study of society, there is no epistemological consensus on what sociology is and on how it should be studied. In particular, over the past few decades, the discipline has mostly become, to borrow the words of Anderson (2000, 77), a research program that "openly assumes an ideological tone palatable to only the most liberal of scholars or ignorant of laymen." But Mises-although it is safe to assume that he would have been vigorously opposed to the epistemological status (or lack thereof) that is assigned to sociology by the current postmodern and neo-Marxist sociologists-died before he could have been aware that such research programs constituted any threat to the social sciences. However, he often discussed the sociology of many of the founders of the discipline such as that of Auguste Comte, Émile Durkheim, and, in much greater length, of Max Weber. In short, there are three meanings of the term "sociology" that were addressed by Mises: 1) sociology as praxeology, 2) holistic sociology (Comte, Durkheim), and 3) interpretive sociology (Weber). It is by analyzing what Mises had to say about each one of these meanings that we will be able to understand whether he considered sociology as a theoretical or a historical discipline. 
Mises himself first termed "sociology" the theoretical science of human action. But he later deemed this to be a mistake, and changed the name of this science to "praxeology." The reason for this was that the name sociology became widely used in a different sense than that used by Mises (Hülsmann 2007, 720). Sociology, Mises tells us-referring in particular to Weber's work-is practiced as a discipline of descriptive or general history (Mises [1949] 1998, 30 n.1), not as the theoretical study of the logic of action. In his Memoirs, he wrote:

[...] I made the mistake of using the term "sociology" to designate the theory of human action. I should have used the term "praxeology." That which one generally calls sociology today is not theoretical, but historical knowledge. Max Weber was quite right in describing what he saw to be sociology in terms of the humanities. He observed that this was the sociology that worked with the formation of ideal types. His error lay in assigning to it many praxeological elements and in seeing economics as a field serviced by the intellectual methods of understanding. My essay ["Sociology and History"] was primarily directed against Max Weber's epistemology, about which I raised two objections: its failure to comprehend the epistemological characteristics of economics, and its distinction between rational actions and actions oriented otherwise. (Mises 2009, 106-07).

We will discuss in greater details the sociology of Weber later on. Suffice it to say here that the meaning of sociology as praxeology has been abandoned by Mises, and that, therefore, each time he refers to the term "sociology" in his earlier work (up to his 1929 essay "Sociology and History"), he refers to something quite distinct from what Weber (and many others) meant by the term.

The second meaning of the term that was addressed by Mises is the holistic sociologies of Comte and Durkheim. To say the least, he did not consider them to be very promising. The research program of Comte - the attempt to reproduce the methods of the natural sciences to the study of the social world (earlier called physique sociale), which then becomes an analysis of the necessary stages of human history (human "progress") allowing us to predict the future evolution of society (Comte 1839, 450-70) -is characterized by Mises ([1957] 2007, 241) as "so shallow and impractical that no serious attempt was ever made to realize it." That of Durkheim and the Durkheimians-a study of the social world that assigns 
to society the status of an acting entity which imposes its will on the individuals (Durkheim [1895] 1982)—is described as the unsatisfactory result of "arbitrary metaphysical effusions about the recondite meaning and end of the historical process [...]" (Mises [1957] 2007, 242) Sociology is then-in the senses given by Comte, Durkheim, and their followers-not a legitimate field of study, and we cannot, therefore, pass judgment about its epistemological status; it simply does not convey any useful knowledge other than by mere accident.

The third meaning of the term addressed by Mises-Weberian sociology - is worth discussing in more details. On the links between the Misesian epistemology and Weber's work, scholars such as Zafirovski (2010) ${ }^{4}$ have argued that Mises's praxeology is in fact identical or quasi-identical with what Weber termed sociology; it is merely "the Austrian school's version of, alternative to, or different name for, sociology in Max Weber's sense." (Zafirovski 2010, 76) Although this can already be rejected based on the evidence provided earlier, we should nonetheless address the specific arguments that are supposed to support such a claim.

To provide evidence for this claim, Zafirovski first quotes Mises when he writes that "[sociology] promised to substitute true science for the rubbish and empty gossiping of the historians in developing an aposteriori science of 'social laws' to be derived from historical experience." (Mises [1957] 2007, 308). Zafirovski (2010, 83) then adds that Mises thought of praxeology as being this "true science." Combined with the fact that Mises elsewhere indicates a correspondence between general sociology and Weberian sociology, this is supposed to imply that the terms "praxeology" and "Weberian sociology" are interchangeable. However, Zafirovski's argument completely ignores what Mises wrote in the following paragraph of the same page, that is: "Their interpretations [that of the sociologists, including Weber] were in many regards unsatisfactory. They were deluded by many of the fundamental errors of historicism. All but Collingwood failed entirely to recognize the unique epistemological character of economics." (Mises [1957] 2007, 308). In other words, their contributions to history notwithstanding, they failed to understand that history and sociology must be framed

\footnotetext{
${ }^{4}$ One can also find similar claims in Lachmann (1990).
} 
by praxeology (and, in particular, economics) in order to provide correct interpretations of empirical reality. The science of praxeology must thus be recognized as epistemologically distinct from history and Weberian sociology. This, in addition to Mises's explicit rejection of Weberian sociology as theoretical in his Memoirs, is enough evidence to understand that the terms "praxeology" and "Weberian sociology" are not interchangeable. ${ }^{5}$ Weberian sociology is recognized as useful by Mises, but as a historical discipline and not as a theoretical one.

This terminological issue has implications about the way in which one is to understand the Misesian epistemology. For if the view of praxeology as sociology prevails, then one has to ignore or dilute Mises's distinction between theory and history. Indeed, if Weberian sociology is identical to Misesian praxeology (or if there exists a mere difference in degree between them), there is no point in distinguishing between what would then be a quite trivial variation in method, i.e., between the analysis of history through the use of more general ideal types and through the use of less general ideal types. ${ }^{6}$ The point of the Misesian distinction is precisely that the

\footnotetext{
${ }^{5}$ The confusion may lie in the previously mentioned fact that Mises used to term "sociology" what he then decided to call "praxeology" and on the other fact that Mises was appreciative of Weber's work. This confusion is especially apparent throughout Zafirovski's paper. After wrongly indicating that praxeology and Weberian sociology are identical or quasi-identical, he attempts to distinguish it from history in order to give to Weberian sociology the epistemological status of theory. To do so, he often cites Mises's books Socialism and Epistemological Problems of Economics and the distinction between "sociology" and history that is presented in it (2010, 77, 82, 84-5). But this is an error of anachronism; the content of these books was written in the 1920s when Mises attempted to name "sociology" the general science of human action. As we have seen, Mises later distinguished sociology (including Weberian sociology) from this science.

${ }^{6}$ This is what Alfred Schütz (1967) attempted to do. Schütz's conception of the ideal type is distinct from that of Weber in at least one major aspect. It takes into account the manner in which we choose the main characteristics to construct it. For Schütz, then, the "ideal types" of "pure economic theory" are constructed based on the universal invariants of human action (they have the highest possible degree of "anonymity") and constitute, as such, necessary truths about action (244). In this sense, there should remain a distinction between the theorems of praxeology and the extra tools used in historical and sociological understanding. The problem is that by subsuming both under the concept of "ideal types" one can easily be confused as to whether there exists an epistemological distinction between the study of theory and that of history. Schütz himself, although agreeing with Mises on the
} 
laws of action constitute necessary transhistorical knowledge about the social world whereas the additional tools of historical analysis are temporary, hypothetical (albeit often useful) constructions.

Indeed, praxeology provides us with a corpus of apodictic, non-hypothetical statements about human action and its logical consequences. True enough, this is often insufficient in order to study in depth an empirical event or trend. A historian or sociologist can then use additional tools or constructions to grasp the social world insofar as these tools do not lead him to reach any conclusion that enters in contradiction with praxeological laws (Mises [1949] 1998, 61). But it is clear that Weberian sociology and the study of history through the construction of temporary and hypothetical ideal types are fundamentally distinct from praxeology.

Now, keeping this in mind, there is no question that Mises was influenced by Weber. The question is: how? And the answer must be, in light of all the evidence, that Weber influenced Mises in his understanding of the proper methods for general historical studies. For, according to the Misesian framework, the Weberian method of sociological inquiry is indeed a useful and appropriate one in the study of history. It considers individuality and rationality as the central points of the understanding of social phenomena, as Mises $(1962,45-6)$ insisted it should. It tries to discover the commonalities and distinctions between various individuals or the reaction of individuals to various social contexts and organizes them into ideal types. In brief, it attempts to attribute a meaning to a historical event or trend. As such, from the point of view of Mises's epistemology, ideal types constitute additional hypothetical tools for the understanding of history (Mises [1949] 1998, 60).

In light of all this, then, what is the epistemological status of sociology according to Mises? The methods of holistic sociology

universality of economic theory, seems to have failed to recognize its aprioristic and non-hypothetical character (Kurrild-Klitgaard 2001, 127-28), which therefore requires different tools of analysis than the a posteriori and hypothetical study of history. A similar-but even more problematic-confusion appears in Lavoie (1986), where it is argued that Mises did not really wish to "dichotomize" theory and history (194) since he thought both were complementary. This is a strange argument for 1) a dichotomy does not imply, as Block (1989, 219-20) correctly pointed out, an absence of complementarity, and 2) Mises was quite emphatic, as has already been shown, in claiming that such a dichotomy exists. 
do not contribute to our knowledge; no epistemological status can thus be assigned to it. Weberian sociology, however, is acceptable when properly understood. This type of sociological research is a part of historical and thymological ${ }^{7}$ studies aimed at providing an understanding of social phenomena. Thus, the epistemological status of sociology is that of general historical analysis such as what a properly understood Weberian sociology envisioned. As such, it must be based on ideal types, methodological individualism, and the actor's rationality.

\subsection{On Methodological Individualism and Rationality}

The absence of methodological cohesion within the sociological profession is one of the key features characterizing the main debates in the discipline. Turner (2001, 3-4) has identified the problem as being a "micro-macro" problem, or an "agency-structure" problem. In short, the methodological debate is about whether social phenomena can be understood as the result of social forces constraining the individual (social structures determine the phenomena) or as the result of individual actions. If social structures are what determine the emergence of social phenomena, then methodological holism (social facts are considered real independent entities influencing one another) would be the correct method to understand the social world, whereas if we can only reconstruct social phenomena through individual actions, then methodological individualism would be the correct method to understand society. ${ }^{8}$

\footnotetext{
${ }^{7}$ Thymology refers to the study of the cognitive origins (or formation) of those elements that motivate action (values, beliefs, ideas, thoughts). See Mises ([1957] 2005, 271-72; 1962, 46-51). French sociologist Raymond Boudon (2003) refined Weber's methods for the study of social phenomena by providing a typology for the rationality of beliefs and values (instrumental, axiological, and cognitive) which one can use in order to understand historical events or trends. This can be seen as an attempt to systematize the historical (thymological) study of values, ideas, and knowledge leading to action.

${ }^{8}$ There exists a variety of solutions suggested to resolve the micro-macro problem. Turner and Boyns $(2001,354)$ identify eight solutions (ranging from what they call "microchauvinism" to "macrochauvinism," and including many midway solutions). Turner's own solution "involves recognizing that social reality does indeed unfold along micro, meso, and macro dimensions; that each of these levels reveals its own emergent properties; that these properties are driven by forces
} 
It is quite clear that, for Mises, every historical (and therefore sociological) analysis must use methodological individualism. Every action is individual action, and its meaning must be thought as individual meaning (Mises 1962, 43-4). This does not imply, of course, that the individual is by necessity "temporally prior" to the collectivity or to various social structures. There exists a multitude of different collectives (built around different goals) to which individuals adhere (Mises [1949] 1998, 42-3). But one must keep in mind that "A collective operates always through the intermediary of one or several individuals [...]" (Ibid.) It is thus only metaphorically that one can attribute an action to a social group: "society itself is neither a substance, nor a power, nor an acting being." (Mises 1962, 78). Such metaphors are often useful. But a scientific analysis may fall into error if it fails to realize that they are indeed mere metaphors.

Weber and Weberians such as sociologist Raymond Boudon understood this. For Boudon, the individual is the ultimate origin of social explanation (Boudon 2010, 16, 27). To both Mises and Boudon, it is only possible to understand a "macrosocial" phenomenon by considering it as the result of a multitude of particular actions and by assembling these particular actions "step by step, part by part." (Mises [1949] 1998, 46). This is what Mises

\footnotetext{
distinctive to each level; that theory is to be about the dynamics of the forces operating at each level; and that theoretical integration will always be about how the properties of one level load the values for the unique forces operating at other levels." (Turner 2001, 6). But this heterogeneity in properties based on the level of analysis can only be considered as heuristically useful, depending on the question asked. It may be admitted that for the mere purpose of describing structural changes then it is sufficient to look at how two structures change together. But to explain it requires that we go deeper. One can describe how the state grows as a result of changes in the structure of central banking, but one certainly does not explain why the structure of central banking changed in the first place or why there would be a causal link simply by doing so. This would require an investigation of typical individual motivations and actions. And surely, if one can only explain macro phenomena by reducing them to (micro) individual actions and motivations, then the macro level is not, ultimately, a completely distinct realm of analysis. To be sure, how a structure (macro phenomenon) emerged is not always relevant to the question asked. Only in this sense is it permissible to argue that structures "constrain" the individual. But these structures, as Mises ([1922] 1951, 315; [1957] $2007,326)$ argued - and Turner and Boyns $(2001,361)$ seem to agree-do not render deterministic explanations; and one must, therefore, still look at typical individual characteristics in order to understand how and why the structure impacted individual thoughts and actions leading to the social phenomena of interest.
} 
called "methodological singularism." It is only by understanding smaller, singular, phenomena that we can understand larger, more complex ones. Likewise, Boudon argued that it is necessary to aggregate typical micro-sociological facts in order to make sense of macrosocial data (Boudon 1986, 16). The macro data can only be heuristically useful in the formulation of enigmas and of hypotheses of investigation (Boudon 1986, 313 n. 11). A cathedral, to adapt one of Mises's examples, provides an enigma: why was it built?; how was it built?; etc. This "macro" datum requires an explanation; we wish to understand something about the processes that made this achievement possible. But, as Mises pointed out, understanding it requires that we reconstruct the actions of the various individuals involved in the project of building this cathedral (Mises [1949] 1998, 45). In the words of Mises: "In studying the actions of individuals, we learn also everything about the collectives and society. For the collective has no existence and reality but in the action of individuals. It comes into existence by ideas that move individuals to behave as members of a definite group and goes out of existence when the persuasive power of these ideas subsides. The only way to a cognition of collectives is the analysis of the conduct of its members." (Mises 1962, 81).

Such an analysis presupposes that we understand acting men as rational men. They have reasons to think what they think and to do what they do. Every action, according to Mises, is necessarily rational in that it always follows a process of thought about the adequation of means towards the achievement of ends. Although Weber allowed, in his typology of social actions, for actions non-rationally oriented (Weber [1922] 1978, 24-5), Weberians such as Boudon have argued that an action can be thus classified only "residually," that is, when it is impossible to understand an action in another way than by classifying it as a result of "impulses" (Boudon 1986, 294 n. 14). To Mises, these "actions" are, of course, mere behaviors. But since Boudon insists on the residual classification of such "actions," there is usually no major contradiction between his and Mises's methods of understanding.

If it is quite clear, then, that-according to the Misesian framework-Weberian sociology proceeds to analyze historical social phenomena in a satisfactory manner, it is not the case for sociologists that deny the validity of methodological individualism 
and rationalism. For instance, Durkheim's method of using aggregated statistical data or legal codes in order to explain collective phenomena (explaining "social facts" by other, temporally prior or concomitant, "social facts") - his methodological holism (see Durkheim [1895] 1982, 162) - presupposes action without properly taking it into account, and is therefore inadequate to provide any explanation at all. It is not "society" that imposes its "will" to the individuals, as Durkheim would have it, thereby allowing for a methodology that merely attempts to describe how an aggregate phenomenon $Y$ followed another aggregate phenomenon $X$ and that somehow pretends to have thus provided an explanation of $Y$. This method simply cannot provide any explanation of $Y$, for it is only a study of individual actions reconstructing phenomena $X$ and $Y$ that can help us elucidate questions such as: why was $X$ followed by $\mathrm{Y}$ ?; must $\mathrm{X}$ necessarily be always followed by Y?; and so forth.

\section{TOPICS OF SOCIOLOGY}

Rationality and individuality, then, are at the center of Mises's analysis of social evolution and devolution. Societies improve or decline based on the degree to which the individuals that compose them understand the benefits of increasing the division of labor.

Praxeology alone can teach us that increasing the division of labor is a process which allows for the maintenance and increase of material standards of living. But to claim that this process constitutes an improvement presupposes that we accept a few empirical assumptions. First, it must be accepted that individual actors generally seek to increase their material conditions of living (Mises [1949] 1998, 180). Indeed, if this were not the case, one could not talk of social progress when labor is further divided. Second, it must be accepted that these same actors tend to have a relatively low time preference, i.e., they do not seek to quickly, and for a short period of time, increase these standards of living at the cost of their long-run standards of living. For if this were not accepted, a society where there is just enough division of labor to have some wealth and where it is possible to fight and steal would still allow many individuals to improve their material wealth in the short-run while sacrificing the long-run process which allows material wealth to grow. Once these hypotheses are accepted, it is possible to better understand Mises's 
analyses of how societies emerge, grow, and fall. The following section will contrast Mises's social analyses to that of some of the major figures of early sociology and derive from them the distinct, praxeologically guided, sociology of Ludwig von Mises.

\subsection{Division of Labor and the Emergence of Society}

The question of the link between division of labor and the evolution of societies has been studied in depth by many sociologists. For instance, French sociologist Émile Durkheim argued that division of labor is the outcome-not the cause-of social development. Indeed, Durkheim criticized Herbert Spencer and the economists for their alleged failure to provide a rigorous explanation of the causes of division of labor. He accuses them of presenting a simplistic explanation, i.e., an explanation according to which isolated individuals suddenly recognize the productive advantage that it implies and that dividing labor will therefore make them happier (Durkheim [1893] 2013, 212).

His argument against this doctrine is, briefly put, that since division of labor has no known limit, if Spencer and the economists were right, then there would be also no known limit to happiness. But the science of psychology indicates that happiness is limited. Therefore, Spencer and the economists failed to explain why we still divide labor further (Durkheim [1893] 2013, 214-15). For Durkheim, the cause of the extension or intensification of the division of labor must thus lie outside of the individual. He finds it in the increases in the volume and density of the population (244). The increases in volume and density imply a larger market, which creates new needs, but also an increase in competition that forces the weaker members of society to specialize in order to survive (251-52). In other words, it is the "struggle to survive" ${ }^{\prime \prime}$ that "forces" an expansion of the division

\footnotetext{
${ }^{9}$ It is unclear if Durkheim employed the terms "struggle to survive" in the usual sense of fighting for scarce resources or in the confused sense of competing for them (or if he subsumed both under the same category). There is, however, a clear distinction between fighting and competing in that the latter allows for the allocation of scarce resources to those who are inclined to provide consumer goods that are more highly valued, whereas the former seeks to deprive others of what they have. See Mises ([1922] 1951, 320-21; 1962, 88).
} 
of labor (248). ${ }^{10}$ For Durkheim, then, division of labor is a consequence of society rather than a cause (241). ${ }^{11}$ It is imposed on the individual actors rather than chosen willingly as a means to prosper.

But these forces are not as "external" to the individual as Durkheim would like them to be. True enough, changes in man's social environment can become problematic. An increase in scarcity (which can indeed be affected by population pressures) decreases the output per capita. This is the Malthusian law of population. But this in no way forces society to divide labor in the same sense that the law of gravitation forces earthly objects to fall when thrown. ${ }^{12}$ Rather, as Mises ([1922] 1951, 293 n.1, 315-16) indicated, division of labor must first be recognized by individuals as a means to increase productivity for it to be extended in order to overcome or alleviate the effects of the struggle for existence that would otherwise prevail.

Far from being something which society imposes on the individual, the division of labor is something which he agrees to participate in because he recognizes it as a solution to a problem. This contradicts Durkheim's classification of the division of labor as what he calls a "social fact," and which he defines as "[...] manners of acting, thinking and feeling external to the individual, which are invested with a coercive power by virtue of which they exercise control over him." (Durkheim [1895] 1982, 52). The increase of the division of labor, for Mises, is a deliberate means that men use in order to achieve their goals more efficiently (Salerno 1990, 28). It is also precisely because of the higher productivity of the division of labor that we can sustain growths in population density and volume, as Mises ([1922] 1951, 293 n.1) indicated, and that we can substitute cooperation for the war of all against all that characterizes the struggle to survive (Mises [1949] 1998, 159, 175, 663).

\footnotetext{
${ }^{10}$ This argument was supposed to contradict Spencer's description of the extension of the division of labor. However, as noted by Perrin (1995, 793-94), Spencer did consider the influence of population pressures as one of the causes of the extension of the division of labor.

${ }^{11}$ This theory is not completely shared by other sociologists. See for instance Georg Simmel ([1900] 1978, 175), who argues that social bonds and societies emerged from exchanges.

${ }^{12}$ Durkheim indeed thought that his theory has the same status in the social world as the law of gravitation has in the natural world. See Durkheim ([1893] 2013, 330 n.1).
} 
Therefore, according to Mises, although it is true that society pre-exists the individual and that man is not born in a cultural or social vacuum (Mises [1922] 1951, 315; [1949] 1998, 143, 164), it is incorrect to argue that society causes cooperation and the division of labor. On the contrary, it is cooperation that allows the creation of sophisticated social bonds such as friendship or love; it is the capacity of man to recognize the superiority of the division of labor as compared to autarky that creates a web of social links which we call civilized society (Mises [1949] 1998, 143-45). Indeed, Mises wrote: "Human society is an intellectual and spiritual phenomenon. It is the outcome of a purposeful utilization of a universal law determining cosmic becoming, viz., the higher productivity of the division of labor." (145). And elsewhere: "Civilization is a product of leisure and the peace of mind that only the division of labor can make possible." (Mises [1922] 1951, 305).

The sociological question of the causes of social evolution and devolution is therefore resolved by Mises. Although Durkheim is right in insisting on the fact that division of labor presupposes at least a primitive form of trust ${ }^{13}$, this is insufficient to demonstrate that social development is merely driven by pressures that are external to the individuals. Indeed, individuals are by no means forced to participate in the division of labor; they do so because they recognize that this is beneficial to the achievement of their various purposes.

It is the division of labor, then, which allows social scientists to distinguish society as the rational form of cooperation it has become from the mere impulses to associate such as what can be found in groups of animals (Mises [1922] 1951,297). It is the variations in the extent and the intensity to which labor is divided that determine the evolution or devolution of society and which make it scientifically understandable (299-300; [1949] 1998, 160). Social evolution is therefore teleological (Mises [1922] 1951, 291; Salerno 1990), i.e., based on the rational thinking of individuals associating in order to overcome or alleviate natural or social problems-to "remove uneasiness," as Mises would put it. It is not the necessary consequence of external sui generis social forces, as Durkheim and other sociologists have argued. Civilization, to Mises, is the purposeful ${ }^{13}$ On the loyalty that characterizes primitive tribes, and on how it is the outcome of
ideas, see Mises $(1962,81)$ 
result of an increase in the division of labor and the capital accumulation it allows, whereas social decline is the result of the reduction of the division of labor.

To understand social history, then, sociology must first identify whether and how the individuals are willing to extend the division of labor. It must describe how societies and civilization historically evolved or devolved by using this general criterion.

\subsection{The Social Effects of Socialism and Capitalism}

One of the effects of socialism, Mises ([1922] 1951, 458, 497) indicates, is to destroy the division of labor, and, therefore, civilization. The opposite is the case for capitalism. It is because the market economy is based on the division of labor that it is possible to "regard each other as comrades in a joint struggle for welfare, rather than as competitors in a struggle for existence." (Mises [1922] 1951, 294-95) Thus, according to Mises, capitalism allows us to see our neighbor as a friend rather than a foe, for we do not see him as someone that will deprive us of scarce resources, but as someone with whom we can exchange and prosper. In other words, capitalism allowed for civilization to emerge because it presupposes a division of labor that bridges the potential divisions between men. As Mises pointed out, it is vain to try to preserve civilization without preserving capitalism because high culture and polite society rest on economic means that can only be obtained in a sufficient amount when the division of labor is unimpaired by state intervention (310). Thus, capitalism allows society to civilize itself whereas socialism dismantles it.

Indeed, for Mises, the erosion of civilization is inevitable under socialism. Dissenting opinions are to be prohibited, for only the central authority (not the consumers) has the power to decide what is allowed and what is not. With the socialist regime being in charge of the allocation of all scarce resources, it is impossible, for instance, for any scientist, artist or writer to seek funds in another way than to satisfy those who are in charge of this regime (Mises [1922] 1951, 188-89). Thus, socialism puts an end to some of the highest achievements of civilization - arts and sciences. In stark contrast, a capitalist society allows anyone to sell his artistic or scientific work to the public or to find a sponsor (189). 
Indeed, Mises (194) writes, capitalism protects freedom. Not in the sense that it annihilates the costs of all actions of course, but rather in the sense that it allows individuals to be protected against arbitrary rules to a larger extent than any alternative system (192-94). One must not see freedom as the absence of rules, but rather as the absence of arbitrary rules. Indeed, some rules are unavoidable if one wishes to live in a society. If one desires to obtain the economic benefits of the division of labor and the social benefits of friendship, love, and cooperation, then one must adapt his actions in light of what the others desire.

But the rules imposed by the State are arbitrary. The State is not capable of meaningful economic calculation, and can therefore not adapt its action with the preferences of society. It is bound to make decisions and create rules that are merely based on the preferences of the ruling class (Mises [1922] 1951, 195). Indeed, economic calculation based on private property renders the cost of many actions more apparent than it would be otherwise (Mises [1949] 1998, 230); it allows for the estimation of how various actions will be profitable (Salerno 1990, 48). Hence capitalism, by making the satisfaction of consumers a condition of possibility for profit, makes it clear that there exists a bilateral dependency between the producer and the consumer: the producer depends on the consumer because he needs to sell goods in order to become a consumer himself and the consumer depends on the producer because he needs to obtain goods in order to maintain or improve his standards of living. The freedom to trade allows for this fact to be understood and for one to see one's fellow men as allies in the achievement of his own goals. And this freedom, by favoring the increase of the division of labor, provides society with the means to evolve into civilization.

We can now be more precise as to how sociology must describe the evolution of societies. It is by observing how socialistic or capitalistic a society is that one can understand its evolution. Because capitalism is the economic system allowing for an extension of the division of labor and because socialism destroys it, a sociologist can analyze social evolution by looking at whether and to what extent capitalism prevails in a given society. 


\subsection{On Class Conflicts}

Mises wrote quite a lot on group or class conflicts. To be sure, his analysis of class conflicts is very different from the most famous one (and one of the most widely used in sociological analyses), i.e., that of Karl Marx. True, Marx's analysis of class conflicts stems from the identification of an important question: Why is it that several groups within society seem to dislike or fight one another? But this is already giving too much credit to Marx. Indeed, class analysis was already used by many economists and social scientists before him. For instance, the non-socialist French industrialists-in particular Charles Dunoyer-had already delineated a framework for class analysis before (Leroux 2016, 86). It thus comes as no surprise that Mises's own class analysis is much closer to that of Dunoyer and other French classical liberals than to that of Marx and the Marxists. ${ }^{14}$

The question that both Marx and Mises attempted to answer is: why are there clashes between groups within society? The Marxist answer to this question is based on historical material conditions of production and class consciousness (Lukács [1923] 1971). It is because a dominated class is composed of individuals who realize the singularity of their own class with respect to its links to the material conditions of their time that irreconcilable interests become conflicts with the other-dominant-class. Under capitalism, the capital owners are the oppressors and have a common interest to keep and extend their "domination" over those who do not own the means of production. The laborers (proletarians) are the oppressed and, once they realize their oppression, have an interest in destroying the capitalist system which captures the plus-value of their labor (Marx and Engels [1848] 2012). According to the Marxists, there is only one way to arrive to a general state of peaceful interactions within society: one class (the proletarians) must violently take control of society as a whole and impose its own will on it. ${ }^{15}$ Mises calls it the "peace of the graveyard," as opposed

\footnotetext{
${ }^{14}$ This has been pointed out by Murray Rothbard in his 1978 preface to Mises's The Clash of Group Interests. See Rothbard (2011, ix).

${ }^{15}$ Mises (1990, 210-11) writes: “The Marxians promise us peace for the time after the final victory of the proletarians, precisely, in the words of Marx, after the working class will have passed 'through long struggles, through a whole series of historical processes, wholly transforming both circumstances and men'."
} 
to liberalism's "peace of progress" (Mises [1922] 1951, 85).

But, as Mises pointed out many times, Marx's class theory is, at best, unconvincing. One can indeed proceed to class distinctions based on the economic concepts of labor or capital in order to scientifically establish the distinctions between what it is to be a laborer and what it is to be a capital owner (Mises [1922] 1951, 331-32). But, first, the mere fact that such a distinction can be done for scientific purposes is no proof that the interests of the laborers are homogeneous or that the interests of the capital owners are homogeneous; and second, even if this were the case, it is still no proof that the interests of the laborer and that of the capital owner are necessarily opposed (in fact, quite the opposite is the truth: the so-called "oppressed" accepts, under capitalism, to exchange his labor time for an immediate income, see Mises [1922] 1951, 334-35).

Instead, argued Mises, class antagonism is the result of state privileges. One needs to explain why, given the heterogeneity in values and interests between various groups, they cannot coexist peacefully. For a variation in values and interests is not a sufficient condition to explain why one group pursues its own interests at the expense of another group. One must also look at the social context which constitutes the vector translating this original heterogeneity of group interests to the resulting situation of conflict. And this social context, for Mises, is the lack of respect for private property rights and for the market economy. In other words, it is because of the state's redistributive or restrictive policies that diverging interests become class conflicts (Mises [1945] 2011, 10). Class conflicts, then, can only occur between two broadly conceived (and internally changing) classes: those who obtain privileges through the state, and those who must pay the price of these privileges; the productive class and the expropriating class (Hoppe 1990, 83-4).

Without State privileges, despite the multiplicity of individual or group interests, no group can advance its own interests at the expense of another (Mises [1945] 2011, 7). For Mises, a more general kind of "interests," which he calls "long-run" or "rightly understood" interests, corresponds to this idea that specific interests can always, in the long-run, be realized more efficiently and without conflict in a market economy. Thus, Mises writes that the "rightly 
understood" interests are "harmonious" (16-7). ${ }^{16}$ Not in the sense that all specific interests become exactly the same of course, but in the sense that their heterogeneity does not systematically lead to conflict and predation within society. In other words, the only way to achieve one's most desired goals in a free market is to be able to first produce what the other members of society desire. It is in this sense that, although different, all interests are harmonious; everybody profits from the fact that everybody else achieves his goals. Systematic clashes cannot occur without state privileges: "Under free trade," Mises tells us, "the manufacturers of shoes are simply competitors. They can be welded together into a group with solidarity of interests only when privileges supervenes, e.g., a tariff on shoes (privilegium favorabile) or a law discriminating against them for the benefit of some other people (privilegium odiosum)." (7).

Thus, in this perspective, we may understand social evolution or devolution by defining two broad classes: those who participate in and extend the process of division of labor (those who make a living by attempting to produce what is desired by consumers) and those who benefit from its destruction in the short-run (those who receive privileges from the state). The first class (the productive class or, using the French classical liberal terminology, the spoliés or the industrieux) is struggling in a fight against the second class (the spoliateurs). ${ }^{17}$ It is the task of history and sociology to identify the specific composition of these classes and to describe their interactions at any given time and place.

In order to assess the extent to which capitalism prevails (and, consequently, the extent to which division of labor and social evolution occur), a sociologist must then look at the specific group conflicts occurring in a society and their singularities. He must identify the composition of the productive class and of the parasitic

\footnotetext{
${ }^{16}$ As Leroux $(2011,136)$ noted, Mises's formulation is very similar to that of Frédéric Bastiat.

${ }^{17}$ It becomes immediately clear what Marx's mistake was; it was a misidentification of the "exploiters" and the "exploited" (Hoppe 1990, 83-5, 92 n.13). The whole history of mankind under statist conditions can indeed be understood by describing class conflicts between the productive class and the parasitic class. This is not the case with the arbitrary class distinctions of the Marxists. For a more detailed analysis of the similarities and differences between the Marxist and the Austrian theory of class conflicts, see Hoppe (1990).
} 
class in order to understand the particular elements of socialism that prevent social evolution.

\subsection{Ideology and the Role of Ideas}

All of this leads to a final question: given that increasing the division of labor reduces class conflicts and leads to social evolution whereas the reduction of it leads to more class conflicts and social devolution, what factors determine the shift of societies towards one or the other? The most important factor, according to Mises, is the role of ideas and of ideology.

Vilfredo Pareto thought that what can convince a population to adopt certain ideas or ideologies are emotions or sentiments rather than reason (Valade 1990,147). This is why, in his opinion, socialist ideas triumphed over classical liberal ideas. The former were defended by appealing to emotionally pleasing utopian promises whereas the latter were generally defended by mere arguments (Pareto 1902, 66-7). Some actions and ideas are therefore irrational. And this was the foundation of his sociology, i.e., the study of "non-logical" actions (Pareto 1917, 76; Valade 1990, 265).

In contrast, for Mises, there is no such thing as "non-logical actions." Indeed, we have already seen that, according to him, every action must be conceived as rational to be understandable. There is no point in arguing against Pareto that emotions and sentiments play a role in shaping ideas. However, as Boudon for instance maintained, the manner in which passions are oriented is not intrinsic to them (Fillieule 2014, 102). Anger, for instance, can be used to appeal for either socialistic or capitalistic ideas. One must provide the public with justifications for why they should be angry at capitalism in order to convince them to support socialism. One must provide a plausible justification for attributing to capitalism an event or condition that makes people angry. Actions will be guided by accepted ideas.

Indeed, Mises ([1949] 1998, 177) argued that ideas and the process of thinking are presupposed by any action. The origin of these ideas is social, i.e., thought is always influenced by the social context of an individual. But this does not imply that society has any thoughts of its own that it imposes on the individuals (Mises 
1990, 290-91). Only individuals can think. The individual must thus reconstruct, in his own mind, the ideas that he encounters in society into an ideology. For Mises ([1949] 1998, 178), an ideology includes elements of scientific ideas and elements of moral ideas. Praxeology has nothing to say about moral ideas, according to him. But from the moment we know or assume to know the ultimate ends of individuals, praxeology can judge the quality of the means that are thought to bring about the desired ends. Thus, any ideology aiming at human prosperity that is in any way antithetical to the division of labor will lead to failure (Mises [1949] 1998, 180-84). But describing how or why such ideology is accepted and how it is connected to a particular social change is a matter of history or thymology. And contextual rationality can be used as an additional tool to understand an ideology and the manner by which it spreads. ${ }^{18}$

For instance, Mises ([1922] 1951, 358) writes that the workers' typical adherence to socialism can be understood by looking at what, given their social context, can lead them to accept the tenets of the socialist doctrine. Mises indicates:

The workman in the large or medium scale capitalist enterprise sees and knows nothing of the connections uniting the individual parts of the work to the economic system as a whole. His horizon as worker and producer does not extend beyond the process which is his task. He holds that he alone is a productive member of society, and thinks that everyone, engineer and overseer equally well as entrepreneur, who does not, like himself, stand at the machine or carry loads, is a parasite. Even the bank clerk believes that he alone is actively productive in banking, that he earns the profit of the undertaking, and that the manager who concludes transactions is a superfluity, easily replaceable without loss. Now from where he stands, the worker cannot see how things hang together. He might find out by means of hard thinking and the aid of books, never from the facts of his own working environment. Just as the average man can only conclude from the facts of daily experience that the earth stands still and the sun moves from east to west, so the worker, judging by his own experience can never arrive at a true knowledge of the nature and functioning of economic life. (Mises [1922] 1951, 358)

Given this fact, it becomes easier for the socialist ideologue to argue that it is the economic system of capitalism which makes the

\footnotetext{
${ }^{18}$ This was noted by Fillieule $(2014,100-02)$.
} 
workers' tasks underappreciated, and that substituting socialism for capitalism would bring them greater wealth and recognition. This helps shaping their own beliefs: "The masses incline towards Socialism, not because it really tends to their interests but because they believe that it does so." (Mises [1922] 1951, 358) An ideology is propagated through the use of reasons provided to the public with the aid of which they can make sense of their own local situation and orient their passions (see Boudon 1986).

It is precisely because some actors are more prone to commit such errors that they support socialism; these actors truly believe that the market economy leads to an outcome which is ethically or economically undesirable, and this is the exact reason why they oppose it. It is without any doubt his belief that ideas are the driving force of action that led Mises to carefully address the mistakes of the socialist doctrine. For once the public is aware of them, it becomes difficult to implement it. True enough, resentment of those who succeed under capitalism can still be felt (see Mises [1956] 2008). But resentment does not constitute an argument. And once all arguments in favor of socialism are shown to be invalid, it becomes increasingly difficult to orient the public's passions against capitalism: "Only ideas can overcome ideas and it is only the ideas of Capitalism and of Liberalism that can overcome Socialism. Only by a battle of ideas can a decision be reached." (Mises [1922] 1951,507)

To those like Pareto who believe that reason can never triumph over passions, Mises responds: "This pessimistic point of view is completely mistaken in its estimate of the influence which rational and quiet reflection can exercise on the masses. It also exaggerates enormously the importance of the part played by the masses, and consequently mass-psychological elements, in creating and forming the predominant ideas of an epoch." (Mises [1922] 1951, 507-08) Since the masses are much less prone to think about ideas, they tend to accept the ideas of those who have the time and ability to do so (Ibid.). Educating the thinkers can then influence the ideas of the masses, which can then allow capitalism to triumph over socialism (510). But, it is true, the opposite can also occur.

It is ideas, then, as was also pointed out by Salerno (1990, 53), that are the driving forces of social change for Mises. And it is the task of history and sociology to study the variations in the spread 
of ideas and ideologies in order to understand social evolution or devolution (Mises 1990, 295, 297-98). Their task is to inquire about the reasons that made an idea consistent with the extension of the division of labor spread to the population sufficiently to bring social evolution (or that made an idea that is inconsistent with it spread to slow down or reverse this evolution).

Now let us sum up everything that has been said in the second section of this paper. Mises provided us with a general framework of understanding for sociological inquiries. In light of this, a sociologist must identify the reasons that made specific ideas prevail in society or in some of its parts. This can explain the specific composition of the productive class and the unproductive class of a society. This class composition then informs us on how, specifically, and to what extent, socialism or capitalism prevailed in a society. In turn, this explains how a society evolved or devolved, since capitalism leads to an increase in the division of labor whereas socialism leads to a decrease in it. We can thus, following Mises's methodological singularism, reconstruct step by step the evolution or devolution of society while answering many singular sociological questions along the way. With all these insights, sociologists can usefully contribute to our understanding of social phenomena and social changes that occurred throughout history.

\section{CONCLUSION}

It has been shown in this paper that Ludwig von Mises, although primarily an economist, has addressed both the epistemological questions and many of the controversial topics of the discipline of sociology. In brief, sociology is a historical discipline. Its main task is to provide us with an understanding of actions and the results of actions that occurred in the past or are likely to occur in the future. It must in particular attempt to find the values and ideas that influenced the shift towards social evolution or devolution. It must also attempt to identify the reasons why these values and ideas prevailed.

To do so, praxeology is necessary but insufficient; sociology must use additional tools to analyze the social world. It must have specific criteria on which to base its judgements about social 
evolution or devolution, i.e., the extension or destruction of the process of division of labor. It must assume contextual rationality and use methodological individualism in order to identify whether and why different groups of individuals shared the values and ideas they had at the time and place they had them. It must find out if these values and ideas were consistent or antithetical to social evolution and connect them to historical trends. It requires the identification of classes of individuals based on whether their ideas, values, and actions were consistent or antithetical to social evolution. In brief, sociology must be a praxeologically oriented study of general history. In strike contrast to holistic sociology, a Misesian sociology (not unlike a properly understood Weberian or Boudonian sociology) is first interested in the individual and his rationality in order to understand larger complex social phenomena.

As such, and by considering "macrosocial" phenomena such as society or culture as the result of individual actions and interactions based on ideas ("microsocial" phenomena), Misesian sociology allows for a better understanding and explanation of social change than by considering macro phenomena as the ultimate bases of social explanations or by considering both macro phenomena and micro phenomena as analytically independent entities of equal importance in providing explanations. Contrary to contemporary metatheories such as that of George Ritzer (see Ritzer and Stepnisky 2018, 596-600), which often correctly assert that there exist interactions between the micro and the macro levels of explanation but fail to recognize the more fundamental character of action and thought in our understanding of social phenomena, Mises's allows us to reconstruct macrosocial phenomena of interest from their ultimate origins in actions and ideas. Even when, from a strictly analytical perspective, an explanation seems to be only involving macrosocial phenomena, one can upon further investigation recognize that, ultimately, the proper explanation is rooted in actions and ideas. For instance, an increase in population can indeed explain why we divide labor more, as Durkheim argued, but this is only because individual actors recognize that dividing labor more is a means to avoid the decrease in standards of living it would otherwise bring. And the ultimate explanation for population increases must also be found in actions and ideas. Failing to recognize such microsocial origins to macrosocial phenomena can 
lead to the erroneous belief that individuals play only a very minor role (if any) in the formation of their own thoughts and actions, as Durkheim thought; the individual's ideas and actions are then merely seen as the unavoidable result of deterministic social forces that are imposed on him. Although it is often heuristically useful to consider an aggregate social phenomenon as given in order to explain some other phenomena, one must always keep in mind while doing so that these social phenomena are ultimately rooted in actions and ideas.

These many insights of Mises can help sociologists (or economists interested in complementing their work with sociology) reconstruct the discipline of sociology on firmer grounds.

\section{REFERENCES}

Anderson, William R., Jr. 2000. "Manuel Castells and the Decline of Twentieth-Century Sociology." Quarterly Journal of Austrian Economics 3, no. 4: 77-89.

—_. 2004. "Mises versus Weber on Bureaucracy and Sociological Method." Quarterly Journal of Austrian Economics 18, no. 1: 1־-29.

Block, Walter. 1989. "A Look at Subjectivism, Intelligibility and Economic Understanding: Essays in Honor of Ludwig M. Lachmann on his Eightieth Birthday." Review of Austrian Economics 3, no. 1: 215-36.

Boettke, Peter J. and Virgil Henry Storr. 2002. "Post-Classical Political Economy: Polity, Society and Economy in Weber, Mises and Hayek." American Journal of Economics and Sociology 61, no. 1: 161-91.

Boudon, Raymond. 1986. L'idéologie ou l'origine des idées reçues. Paris: Fayard.

—. 2003. Raison, bonnes raisons. Paris: Presses Universitaires de France.

—_. 2010. La sociologie comme science. Paris: La découverte.

Callahan, Gene. 2007. "Reconciling Weber and Mises on Understanding Human Action." American Journal of Economics and Sociology 66, no. 5: 889-99.

Comte, Auguste. 1839. Cours de philosophie positive. Vol. IV. Paris: Bachelier. 
Dorobăț, Carmen Elena. 2015. “Division of Labor and Society: The Social Rationalism of Mises and Destutt de Tracy." Quarterly Journal of Austrian Economics 18, no. 4: 436-55.

Durkheim, Émile. [1893] 2013. De la division du travail social. $8^{\text {th }}$ ed. Quadrige. Paris: Presses Universitaires de France.

— [1895] 1982. The Rules of Sociological Method, trans. W. D. Halls. New York: Free Press.

Fillieule, Renaud. 2014. "Raymond Boudon as Social Theorist: A Comparison with Ludwig von Mises." Journal des économistes et des études humaines 20, no. 2: 91-128.

Hoppe, Hans-Hermann. 1989. "In Defense of Extreme Rationalism: Thoughts on Donald McCloskey's The Rhetoric of Economics." Review of Austrian Economics 3: 179-214.

_ 1990. "Marxist and Austrian Class Analysis." Journal of Libertarian Studies 9, no. 2: 79-93.

- 1995. Economic Science and the Austrian Method. Auburn, Ala.: Ludwig von Mises Institute.

—. 1997. “On Certainty and Uncertainty, Or: How Rational Can Our Expectations Be?" Review of Austrian Economics 10, no. 1: 49-78.

Hülsmann, Jörg Guido. 2007. Mises: The Last Knight of Liberalism. Auburn, Ala.: Ludwig von Mises Institute.

Kurrild-Klitgaard, Peter. 2001. “On Rationality, Ideal Types and Economics: Alfred Schütz and the Austrian School." Review of Austrian Economics 14, nos. 2-3: 119-43.

Lachmann, Ludwig M. 1990. "Austrian Economics: A Hermeneutic Approach." In Economics and Hermeneutics, ed. D. Lavoie. London and New York: Routledge.

Lavoie, Don. 1986. “Euclideanism versus Hermeneutics: A Reinterpretation of Misesian Apriorism." In Subjectivism, Intelligibility and Economic Understanding. Essays in Honor of Ludwig M. Lachmann on his Eightieth Birthday, ed. Israel M. Kirzner. London: Macmillan.

Leroux, Robert. 2011. Political Economy and Liberalism in France. The Contributions of Frédéric Bastiat. Abingdon: Routledge. 
- 2016. The Foundations of Industrialism. Charles Comte, Charles Dunoyer, and Liberal Thought in France. New York: Peter Lang.

Lukács, Georg. [1923] 1971. History and Class Consciousness. Cambridge: MIT Press.

Marx, Karl and Friedrich Engels. [1848] 2012. The Communist Manifesto. New Haven and London: Yale University Press.

Mises, Ludwig von. [1912] 1953. The Theory of Money and Credit, trans. H. E. Batson. New Haven: Yale University Press.

__ [1920] 1963. "Economic Calculation in the Socialist Commonwealth." In Collectivist Economic Planning. Critical Studies on the Possibilities of Socialism, ed. F. A. Hayek. London: Routledge and Kegan Paul.

__. [1922] 1951. Socialism: An Economic and Sociological Analysis, trans. J. Kahane. New Haven: Yale University Press.

—_ [1945] 2011. The Clash of Group Interests. Auburn, Ala.: Ludwig von Mises Institute.

—. [1949] 1998. Human Action. A Treatise on Economics. Auburn, Ala.: Ludwig von Mises Institute.

—. [1956] 2008. The Anti-Capitalistic Mentality. Auburn, Ala.: Ludwig von Mises Institute.

- [1957] 2007. Theory and History. An Interpretation of Social and Economic Evolution. Auburn, Ala.: Ludwig von Mises Institute.

- 1962. The Ultimate Foundation of Economic Science. An Essay on Method. Princeton: D. van Nostrand.

- 1990. Money, Method, and the Market Process. Essays by Ludwig von Mises, ed. R. M. Ebeling. Norwell: Kluwer.

—. 2009. Memoirs. Auburn, Ala.: Ludwig von Mises Institute.

Pareto, Vilfredo. 1902. Les systèmes socialistes. Vol. 2. Paris: Giard and Brière.

—. 1917. Traité de sociologie générale. Vol 1. Paris: Payot and Cie.

Perrin, Robert G. 1995. “Émile Durkheim's 'Division of Labor' and the Shadow of Herbert Spencer." The Sociological Quarterly 36, no. 4: 791-808. 
Ritzer, George and Jeffrey Stepnisky. 2018. Sociological Theory. $10^{\text {th }}$ ed. Los Angeles: Sage.

Rothbard, Murray N. 2011. "Preface." In Ludwig von Mises, The Clash of Group Interests. Auburn, Ala.: Ludwig von Mises Institute.

Salerno, Joseph T. 1990. "Ludwig von Mises as Social Rationalist." Review of Austrian Economics 4, no. 1: 26-54.

Schütz, Alfred. 1967. The Phenomenology of the Social World. Evanston, Ill.: Northwestern University Press.

Simmel, Georg. [1900] 1978. The Philosophy of Money, trans. T. Bottomore and D. Frisby. London, Henley and Boston: Routledge and Kegan Paul.

Turner, Jonathan H. 2001. "Sociological Theory Today." In Handbook of Sociological Theory, ed. Jonathan H. Turner. New York: Springer.

Turner, Jonathan H. and David E. Boyns. 2001. "Return of Grand Theory." In Handbook of Sociological Theory, ed. Jonathan H. Turner. New York: Springer.

Valade, Bernard. 1990. Pareto. La naissance d'une autre sociologie. Paris: Presses Universitaires de France.

Weber, Max. [1922] 1978. Economy and Society. An Outline of Interpretive Sociology, ed. G. Roth and C. Wittich. Berkeley and Los Angeles: University of California Press.

Zafirovski, Milan. 2010. “Weber's Sociological Elements in Mises's Economics of Human Action." Social Epistemology 24, no. 2: 75-98. 